\title{
Place, belonging and the determinants of volunteering
}

Dallimore, David; Davis, Howard; Eichsteller, Marta; Mann, Robin

\section{Voluntary Sector Review}

\author{
DOI: \\ 10.1332/204080518X15161941913849 \\ Published: 01/03/2018 \\ Peer reviewed version \\ Cyswllt i'r cyhoeddiad / Link to publication
}

Dyfyniad o'r fersiwn a gyhoeddwyd / Citation for published version (APA):

Dallimore, D., Davis, H., Eichsteller, M., \& Mann, R. (2018). Place, belonging and the determinants of volunteering. Voluntary Sector Review, 9(1), 21-38.

https://doi.org/10.1332/204080518X15161941913849

\footnotetext{
Hawliau Cyffredinol / General rights

Copyright and moral rights for the publications made accessible in the public portal are retained by the authors and/or other copyright owners and it is a condition of accessing publications that users recognise and abide by the legal requirements associated with these rights.

- Users may download and print one copy of any publication from the public portal for the purpose of private study or research.

- You may not further distribute the material or use it for any profit-making activity or commercial gain

- You may freely distribute the URL identifying the publication in the public portal ?
}

Take down policy

If you believe that this document breaches copyright please contact us providing details, and we will remove access to the work immediately and investigate your claim. 


\title{
Place, belonging and the determinants of volunteering
}

Authors: David J. Dallimore, Howard Davis, Marta Eichsteller, Robin Mann (Bangor University)

Keywords: volunteering; belonging; place and space; ethnography

Corresponding Author: David J. Dallimore Bangor University Bangor, Gwynedd UNITED KINGDOM

This paper is based on research supported by the Wales Institute of Social \& Economic Research,

Data \& Methods (WISERD). WISERD is a collaborative venture between the Universities of

Aberystwyth, Bangor, Cardiff, South Wales and Swansea. The research that this paper relates to was funded by the ESRC (grant number: ES/L009099/1)

\begin{abstract}
:
In this paper we discuss findings from our ethnography investigating how volunteering in local associational life is changing, asking whether structural factors fixed in localities remain important, or whether as others have suggested, volunteering is becoming disembedded from place. Across two locations we observe how situational variables including belonging, identification and interaction remain important determinants of volunteering, and how the relationship between people and their localities has distinct meanings. In one locality, people participated as volunteers because they had a strong sense of belonging, in the other, they often volunteered because they wanted to belong. We conclude that local voluntary association is important in forming bridges between people in 'places' and wider society, but find that differing notions of belonging mean that localities are not equally situated to operate as effective conduits. We conclude that understanding these dynamics is important for outside agencies in delivering support and public services.
\end{abstract}




\section{Introduction}

Discussion about the nature, extent and trajectory of volunteering as an indicator of the health of numerous social worlds (variously described as neighbourhoods, localities, communities or civil societies) is prolific in recent literature (eg, Wollebaek and Selle, 2002; Rochester, 2013). Much social commentary and public discourse focuses on the impact of associational activity on social change. Arguments put forward by commentators such as Putnam pronounce the decline of 'serious volunteering' (2001, p.70) and warn of grave consequences as citizens become increasingly socially disoriented and given to highly individualized activities at the expense of civic engagement or communal life (Fine and Harrington, 2004). Yet data shows that traditional volunteering, involving long-term commitment to communal organisational development in the UK, remains steady (Cabinet Office, 2015). With such evidence, debates have shifted towards a focus on changes in the nature of volunteering rather than the extent. It is argued that because of social and cultural change, volunteering is shifting towards more individualistic (Curtis, 2015; Eckstein, 2001; Hustinx, 2010), episodic (Rochester, 2013) or goal-orientated (Curtis, 2015; Dean, 2015) activities. A number of studies (Dean, 2014; Handy, Hustinx and Cnaan, 2009) observe changing personal and collective rationales for volunteering and a consequential rise of phenomena such as 'volunteer tourism' (Simpson, 2004) consisting of short placements undertaken by outsiders to the beneficial communities. Such accounts suggest a loosening of bonds between places and those that volunteer in them, as part of a wider process of globalisation where practices become detached from their settings and volunteering becomes 'disembedded' (Hustinx and Meijs, 2011).

Observing empirically how tensions in the practice of volunteering between the 'local' and the 'global' play out would seem to be central in generating insights regarding evolving social change and it is widely accepted that local case studies provide an effective methodology for achieving this (Savage, Bagnall and Longhurst, 2005). Our research explores this in situ, using ethnographic and biographical interview methods to capture both continuity and change within two localities in North 
Wales. Within these places we find, not uncommonly, a wide range of small organisations or collectives that can be defined as 'grassroots associations' (Smith, 1997) or 'below the radar' groups (Mccabe and Phillimore, 2012). Our investigation is focused on the dynamics of these groups which, by providing space and support, encourage individuals to participate in civic projects and public discourse, and can be seen as the microfoundations of civil society (Fine and Harrington, 2004). The aim of this article is to gain an understanding of how the volunteering that sustains these groups is determined; how it is currently situated in the local; how it has changed in response to broader social and cultural transformations; and what policy implications there may be therein.

To explore these issues we begin with an investigation of the field of volunteering discussing the problematic issue of how volunteering is framed in theory. From this discussion we propose a hybrid analytical framework that we subsequently deploy to interpret the determinants of volunteering within our own empirical evidence. This is followed by a discussion of the findings, exploring how volunteering is situated, and the role that place has in structuring volunteering practices.

We conclude that there is ample evidence of volunteering activity firmly embedded in place and we illustrate this through people's biographies that often define their relationship to localities. We further conclude that this plays out differently depending on the formations and constructions of identity and belonging and note the importance of understanding these dynamics for outside agencies in delivering support and public services.

\section{Background}

Why individuals volunteer has long been of interest to sociologists (Smith, 1994; Wilson, 2000) but according to Hustinx et al. (2010) while multiple theoretical and conceptual models have been generated, no integrated theory of volunteering has been developed. Building on Hustinx et al. (2010) we adopt a 'hybrid conceptual framework of volunteering' with three layers of complexity. The first layer highlights problems with definitions of volunteering, which although many authors 
(e.g. Cnaan, Handy and Wadsworth, 1996) agree often have common characteristics, can be seen to be inconsistent and contradictory (Hustinx et al. 2010). The second layer lies in the complexity involved in viewing the functions of volunteering from differing perspectives - such as economic, psychological or sociological - each examining practice through a particular lens. Third is the complexity evident in framing the determination of volunteering, seeking to understand who volunteers and why they do so. In this paper we focus on the determinants, but do so through sociological enquiry, focusing less on the economic benefits of altruism or the psychology of volunteers, but by seeking to understand volunteering as a social phenomenon within which structural factors are at play as determinants of volunteering, while considering cultural factors that infuse volunteering with value and meaning.

In examining the determinants of volunteering most research focuses on identifying the correlates, and more ambitiously, the causes of such participation. Although a wide range of sub-theories are deployed (see Smith, 1994 p.244) in studying the literature we find a relatively small group of variables that commonly appear.

First, are contextual variables that characterise the environment of the individual, such as the size of community and regional influences. Related, is Cornwall's (2002) concept of 'situated practice' where the places and spaces in which volunteering takes place are framed '... with reference to actual political, social, cultural and historical possibilities' $(2002$, p.3). Viewing volunteering as shaped by local contexts would suggest that places that are superficially similar may produce patterns of involvement that are quite different, requiring a more in-depth exploration of places to fully understand how spaces are opened, or filled.

Secondly, there is a strand of volunteering research that examines situational variables as determinants. According to Smith (1994) these have to do with the symbolic interaction between one individual and another. Having friends already in a group, receiving services from an organisation, or ascribing status to membership, have all been shown to increase volunteering rates. 
As Musick and Wilson (2008) note however, not everyone is asked to be a volunteer, but those who are, are more likely to do so.

Thirdly, the social and economic status of people has been shown to be a consistent correlate with volunteering (Hustinx, Cnaan and Handy, 2010). Smith (1983) conceptualises this as a 'dominant status model' where participation in volunteering '...is generally greater for individuals who are characterized by a more dominant [sociocultural system-valued/preferred] set of social positions and roles, both ascribed and achieved' $(1983$, p.86). While volunteering is not carried out only by those with higher statuses, they volunteer in greater numbers, give more time, fulfil more prestigious positions and undertake more meaningful tasks (Smith, 1994). However, the model is found to be less applicable where there is a high degree of homogeneity within places. Here, the impact of socio-economic status is reduced, often replaced by considerations of cultural standing (Wilson and Musick, 1997).

Finally, and related to the situational variables, is an approach to identifying volunteering determinants as 'habitus' (Bourdieu, 1977) formed of predispositions acquired through practice interacting with social, cultural and economic capitals. People acquire the 'habit' of volunteering because they are placed in social situations and have social relationships where the skills and dispositions towards volunteering are developed (Janoski, Musick and Wilson, 1998). This is highlighted in Dean's work $(2014,2016)$ examining adult volunteering based on pre-adult social attitudes, social participation and early volunteering. There is a common assumption that if volunteering starts early, it will continue with commensurate benefits for civil society (ibid). This theory has been behind many state volunteering policies in recent times with governments promoting 'Service Learning', 'Active Citizenship' and other youth volunteering programmes although there is contradictory evidence of their success (Zaff, Malanchuk and Eccles, 2008; Warburton and Smith, 2003; Henderson, Brown, Pancer and Ellis-Hale, 2007). Smith (1994) highlights attitudinal variables as being frequently investigated as a determinant of volunteering but adds that participation is also affected by the volunteer's pre-existing relationship with the group of 
interest. This is highlighted in the extreme by O'Toole and Grey's (2016) study of volunteer lifeboat crews where a dense web of familial, inter-generational, communal, geographic and historical relationships shapes the volunteering practice. They describe the importance of place in creating and maintaining a sense of self which in turn produces 'thick volunteering' $(2016, p .29)$ rooted in emotional and subjective attachment to a locality.

\section{Methodology}

This study draws on fieldwork from an ESRC funded project 'Civic Participation in Wales in place and over time' examining continuity and change in participation in civil society at a local level. The aim of the project is to develop understandings of how changes in associational forms and the experiences of local civil society participants are shaped by local contexts. This involved the use of ethnographic and biographical interview methods and involved data collection in 2015 and 2016 in two locations.

\section{Choice of Research Sites}

Our sites are both in North East Wales in the UK, and while contrasting have common frames of reference. The first is the large village of Rhosllanerchrugog (Rhos) with a population of 9,694 (ONS, 2011) six miles from the large town of Wrexham. Our second site, just seven miles away is the smaller village of Overton-on-Dee (Overton) which at the 2011 Census had a total population of 3,315. We selected Rhos based on the rich evidence of civic participation, especially in the areas of chapel culture, choir participation and language activism. Overton was selected after emerging evidence of contrasting patterns in civic participation. We were initially encouraged to study Overton by one of our respondents - a local politician - who remarked on the 'unusual' levels of voluntary activity and participation. Through initial visits and study of administrative data we found in Overton a site that in many ways provided a contrast to contextualise the emerging findings from our first site, with factors such as cultural heritage, social class, demography and migration patterns emerging as being important in shaping associative activity. There were nonetheless pragmatic 
factors in our site selection - such as relative proximity to both our research base - and as places where as researchers, we had some prior knowledge and personal contacts that provided essential gateways into each community. While not a primary intention of our research, this approach to choosing our sites of investigation has resulted in locations that share common influences - including the economic and institutional contexts, as well as local government and political representation. The villages are both exceptional in their own ways, and therefore in one sense, atypical. As suggested by Phillipson (2012), studying contrast enables us to develop a richer, more in-depth understanding of the phenomenon of volunteering to lend credibility to the research account while the sites inevitably share similarities with many places that will be familiar elsewhere.

\section{Data Collection}

Fieldwork took place between April 2015 and October 2016 and involved a mixed method approach. Firstly, in each site we engaged in ethnographic observation, gathering evidence of participation and community engagement, as well as researching administrative, historical and public databases for additional contextual information.

Secondly, with an emerging picture of participation we set out to interview local actors that represented the diversity of local association. Twelve people from Rhos and ten people from Overton were interviewed. The selection's aim was to represent a range of local actors volunteering in a variety of local groups and organisations, members of the community councils and local politicians. We used a biographical interview method (Rosenthal, 2004) in order to gather information on the perception of change and continuity within each locality and to gain insight into the identity and belonging mechanisms which shape the relationship between the individual actor and the place, and influence the character of civic participation over time. Biographical narrative interviews provided us with historical context and informed us about continuity and change across social institutions, such as family, employment relations, and religion, and their influence and relationship to volunteering in the two sites, and in some cases, elsewhere. 
Finally, to obtain a wider picture of the scope of civic participation we carried out a 'street survey' using semi-structured interviews with residents (101 in Rhos, 81 in Overton). These were collected in public places including libraries, along the main streets, and at different local events. Informal conversations were also held with people in public settings such as cafes and shops and we attended and collected field notes at a number of events and meetings.

\section{Data analysis}

Transcripts and field notes were coded using NVivo software around particular themes and issues with our analysis looking at answers both across cases and relative to the accounts within cases. Quantitative data from our 'street survey' was analysed using SPSS although with the relatively small samples (C.I.>10) the data analysis is restricted to descriptions of frequencies. Our initial findings were shared at engagement events in each location to which participating individuals and organisations, and the public, were represented. These provided invaluable opportunities to test our findings, answer questions from the communities and provided further valuable evidence in developing our conclusions. We also held meetings with the local authority and the regional voluntary sector body to discuss policy implications and potential utility of our findings.

\section{Determinants of volunteering - comparing Rhos and Overton}

The analysis of our data revealed the complexity of the civic participation in both locations. Throughout the process we struggled with the inconsistent conceptual frameworks regarding participation and volunteering as well as their elusive links with the place and biographical lifespan of these practices. For the purpose of this article we embraced the multidimensional nature of volunteering as laid out by Hustinx et al. (2010) and Smith (1994), and deployed a hybrid analytical framework (see Table 1) to interpret the determinants of volunteering through our own empirical evidence linking the civic participation and biographical accounts of the place. We hope to explore the temporal dimension of civic participation in the next stage of analysis. 


\section{INSERT TABLE 1}

In this section we set out the key findings of our study, observing how the situatedness of practice at the local level has bearing on the main determinants of volunteering as discussed in the literature. We focus on individual cases with the narratives and biographies of our respondents to demonstrate our arguments. While we have clearly identified our sites, individuals mentioned directly or indirectly, have been given pseudonyms.

\section{Contextual variables}

Across the contextual variables both places, Rhos and Overton, regardless of their physical proximity, developed in very different historical context. Rhosllanerchrugog is a large settlement (see Table 2) with some respondents claiming that it was at one time, the largest village in Wales. It certainly has a more urban than rural feel about it. Since the mid nineteenth century Rhos' fortunes have been heavily linked to the rise and subsequent decline of heavy industries both within the village, and in the broader North East Wales area. The Hafod coal mine at the edge of the village, was the major employer until the second half of the twentieth century alongside other industries including iron, quarrying, brick and tile manufacturing. These industries each have their own trajectory, but by the end of twentieth century they had all either ceased operations or undergone a significant restructuring in terms of the number of people employed. After the Second World War the wider area experienced a growth in employment in light manufacturing industries in surrounding areas, but little employment remains in Rhos itself today. Our respondents frequently defined Rhos's working class credentials by its 'chapels and pubs'. A historical connection to Welsh liberal nonconformism is well documented (see Laidlaw, 1995, 168-236) with records suggesting some thirtytwo chapels or churches in the village at the peak of non-conformism in the second half of the nineteenth century (The Chapels Heritage Society, 1988), although only about seven are in regular use today. While some of the associative activity that we observed - such as the choirs - have their roots in chapel culture, the pubs were equally important in the past in producing sports clubs, such 
as Rhos Rovers football club based in the now closed Nags Head pub. A legacy of the mining industry - which recruited workers from many other parts of Wales, and associated chapel culture, is the widespread use of Welsh as a daily language of interaction in the village distinguishing Rhos from its mainly English-speaking surroundings. However, according to recent data (ONS, 2011), Rhos is no longer an overwhelmingly working class village, and just $25 \%$ of Rhos residents speak Welsh. Yet most of the participative activity we observe in Rhos still represents an almost clichéd picture of Welsh working class culture, steeped in industrial, religious and linguistic heritage. Today, Rhos has five active choirs - some of national and international repute - alongside activities such as crown green bowling, rugby and pigeon racing.

Overton is a moderately sized village (Table 2 ) that lies on the banks of the River Dee - the ancient border between Wales and England. The village was granted a Royal Charter by Edward I in 1292 and was an exclave of the traditional county of Flintshire known as Maelor Saesneg (the English Maelor) a sub-division of the Kingdom of Powys. It has strong feudal and agricultural roots, with much of the surrounding area still in the hands of a single landowner. It maintains links to the land, with timber processing, poultry farming and cheese-making enterprises, but today most local residents travel to the local large town of Wrexham and further afield for employment. Twenty-two per cent of Overton adults of working age are employed in higher-level occupations (compared with nine per cent in Rhos) and levels of overall deprivation are considerably lower than the Wales average. While not wholly middle-class, local association in Overton is familiar from previous research (e.g. Pahl, 2005, 2008; Tyler, 2003; Taylor, Phillimore, McCabe and Soteri-Proctor, 2010) with a broad range of clubs, societies and groups including two Women's Institutes, amateur dramatics, twinning association, walking and music groups, and several sports clubs including tennis, cricket and football.

INSERT TABLE 2 
Another contextual variable influencing different forms of civic participation in Rhos and Overton is migration. Both immigration and emigration are factors that emerge in our data that can be observed shaping volunteering and voluntary activity in both localities.

In Rhos, official statistics (See Table 2) show a slowly declining population, but one that is predominantly indigenous. According to the 2011 Census, $82 \%$ of Rhos residents were born in Wales and in our street survey just $28 \%$ of respondents said that they had ever lived anywhere else. The problem of emigration was a common theme that appeared in the narratives of our respondents with the loss of the young, and particularly the well-educated young, seen as having a negative impact on local associational life. David, was a committed local board member of a voluntary organisation struggling to recruit members and facing an uncertain financial future. He describes a process that in other accounts (e.g. Arensberg and Kimball, 1940; Laidlaw, 1995, p.385) has been happening for some decades and has long been identified as a threat to stability within communities:

'...the people who you would have expected to become leaders, they didn't go away in the old days did they, you know? They didn't go to college, or only very few of them did. But the people with the vision and the skills, they were the ones who ran the pits, they ran the industry in the area. But now our elders have decided "well, I don't want you to go down the pit". "You go to college" or "you're going to be something better than what I was." Well the only way to do that is to move away.' (David, Rhos)

Yet many of those that David speaks of maintain strong links to Rhos. Cai, who despite having left Rhos for good as a teenager, visits regularly and is engaged in supporting David's group:

I've had some fantastic experiences revisiting the village, I'm still very much a part of [the organisation] which so desperately needs help' (Cai, Rhos) 
We found other organisations that are supported by a Rhos diaspora, with non-residents maintaining membership of associations or deploying social or economic capital gained elsewhere to support local groups or specific campaigns. We therefore see in Rhos a reflection of Tönnies writing in the 1950's: 'The will and spirit of kinship is not confined within the walls of the house, nor bound up with physical proximity... it can live on by itself, thrive on memory alone and overcome any distance by its feeling and its imagination of nearness and common activity $(1955, \mathrm{p} .43)$.

Immigration was perceived negatively in Rhos (even though statistically it is small - see Table 2), portrayed as a threat to native vernacular culture and local identity:

'Rhos people are not Welsh people now, are they, I mean there are so many, I hesitate to use the word incomers, but there are, you know, - people have come from everywhere now because of cheap housing and social problems elsewhere and they've dumped people in Rhos and all sorts of things haven't they?' (Tony, Rhos)

Yet elsewhere in Tony's and in other accounts, respondents describe how in previous generations Rhos was a 'melting-pot' as people from other areas of Wales and the UK came to the village to work in the mines and other industries, enriching the culture and local participative activity.

In Overton, patterns of migration are very different. Although the number of residents has not changing significantly in recent years, the fact that only $51 \%$ of residents were born in Wales (ONS 2011), and $73 \%$ of respondents to our street survey said that they had previously lived elsewhere, suggests a high population turnover. Most of the local leaders of voluntary organisations are incomers, having moved to Overton with young families often from the Midlands or North West of England, drawn by good schools, or in retirement seeking a better quality of life that they imagine exists in more rural settings. Such patterns have been identified in other studies ranging from Pahl's (1968) seminal work on villages to more recent work by Savage, Bagnall and Longhurst (2005) and Benson and Jackson (2013). As in such studies, we find that not only do the middle class adopt 
places, they actively make and maintain them. However, in contrast to some rural studies (e.g. Harper, 1989; Day, 1998) in Overton we do not find stark division between 'insiders and outsiders' or 'locals and incomers':

'I quite like just a bit of new blood in the village... to have new people coming and just joining in and some of them have got very good ideas haven't they?' (Margaret, Overton)

If there is a rural native / urban incomer divide in Overton then the kinds of associational activity we find would seem to be transformative. Alongside traditionally 'rural' activities such as the Women's Institute and the Flower \& Produce Show we find Ashram Yoga, Town Twinning and a Blues Festival. Perhaps what we see in a village such as Overton is best described by Pahl:

'A village may best be understood as a state of mind. As 'rural' people acquire an urban outlook and 'urban' people try to escape from the physical urban world into an arcadian vision of a 'rural' area...' (Pahl, 1968, p.30)

Cultural urbanisation is enhanced by immigration in Overton creating a greater degree of homogeneity, while in Rhos, immigration and emigration can be seen to emphasise and build upon existing divides.

\section{Situational variables}

We find similar dynamics evident when examining situational evidence. Previous research (e.g. Eckstein, 2001; Smith, 1994) has found that volunteering varies with community homogeneity and a range of data sources point to clear differences within the research sites. In many of our interviews Rhos is portrayed as a distinct entity yet there are clear lines of division. Most obviously, a core of residents dominate formal association, as they have done since the 1960's and probably further back in time. As Laidlaw (1995) found previously in Rhos, and Frankenburg (1957) before him in 'Pentreddiwaith', associations frequently depend on the enthusiasm and charisma of particular 
individuals whose commitment is reflective of their status in the society. In Rhos, the cultural elite share a common social and cultural heritage of non-conformism, Welsh language, and industrial genealogies. While this is evident in the responses to our street survey (see Figure 1), in our participant's narratives many spoke of shared identities in the past tense suggesting a collective memory (Connerton, 1989) of homogeneity that is not present today:

'...there's a very strong sense of roots. There's a very strong sense of identity, the twin identities of the chapel and the coalmines... both have been hugely influential and a lot of the cultures stem from that. And because of the importance of the chapels, and the choirs, the people knew people and that was actually extremely important. There was a very strong sense of, you know, the community leaders, the village elders, if you like, were - and that was very much a part of that' (Alison, Rhos)

The importance of history was frequently mentioned in Rhos, and as Savage (2005) found in the Lancashire town of Ramsbottom was '...an invocation of an industrial working class, which is deemed to still convey authenticity to the local population, even though the industrial base has now almost disappeared' (2005 p.44) and as Connerton further suggests, '...experiences of the present largely depend upon our knowledge of the past, and that our images of the past commonly serve to legitimise a present social order' (1989, p.4).

In Overton, it is the 'newcomers' rather than those more deeply rooted who seem most interested in the past. The local history group collects memories from 'the old families', but it was set up by a couple born and brought up in the English Midlands. Lewicka (2008) showed that awareness of a 'place history' intensifies both 'place attachment' and 'place identity'. While we see considerable evidence of place attachment through knowledge and pride in local history in both villages, in Rhos we observe a far greater incorporation of 'place identity' as part of individual's self. As Lewicka 
writes, '...the former means that one may feel attached to a place but it takes more than liking or attachment to incorporate the place as part of one's self' (2008, p.212).

\section{INSERT FIGURE 1}

The variances in homogeneity therefore result in volunteering playing out differently - and perhaps counter-intuitively - across the two localities. In Rhos, the appearance of a collective identity seems illusory with many voluntary organisations forming an exclusive society within a dense, but minority Welsh culture. Membership of voluntary groups in Overton is in contrast, less about conferring status than reflecting and developing existing social stratification. This is displayed by the ease and speed with which middle-class newcomers are enmeshed in local activity. This is apparent in Diane's story, who shortly after moving to Overton was asked to be part of a group coordinating a visit by the Queen - although she did ruffle a few feathers in the process:

'So that was '93 when we'd been in the village for four years. The Queen's visit was'92 and of course, dealing with the publicity for that meant that I got to know quite a lot of people. Some people not so well, they said, "She's only been here five minutes and she's going to shake hands with the Queen" you know' (Diane, Overton)

Many respondents described how being asked to join a group was their route to volunteering. Paul was '...persuaded to put my name forward for Rhos Community Council' by a friend who was a magistrate, while Aled joined a choir after being asked by a fellow member of the Aelwyd ${ }^{1}$ :

'....one of the members of that society was the conductor of the choir at the time. So I knew him from then and he was the one who suggested, well why don't you come along and see what it's like. And it started from there really. I didn't decide one day I was going to join the choir, it was just something that happened really' (Aled, Rhos)

\footnotetext{
${ }^{1}$ The Aelwyd is a branch of the Urdd organisation - the Welsh League of Youth
} 
Yet as suggested by Wilson and Musick (1997) being asked to volunteer was not something that happens to everyone:

'...the [group] is very protective of who it does have in to volunteer, you know, unless you happen to know someone there your chances of getting in are pretty slim. Oh yeah, we're very selective about who we have as volunteers.' (Tony, Rhos)

Participation in Overton happened similarly, but was less overtly based on ascribed social status and more on the possession of useful capital, as in the case of James:

'...the local Scout leader said, you're good at fundraising James, we need somebody like you to help us run the Scout group. And that was 1982 and I became Group Chairman, I was Group Chairman for four years and then became Group Scout Leader. And I've been Group Scout Leader off and on since then right up to now' (James, Overton)

The situational variation between Rhos and Overton is complicated further by the role of Welsh language. The role that language plays in volunteering within multi-lingual locales has not been widely studied. Mann (2007) makes a link between Welsh language and civic identity within which volunteering or investing in local economy is important, but in our study sites, only in Rhos is this evident. In Overton, fewer than $5 \%$ of adults speak Welsh (ONS, 2011) and language did not feature as an issue in any of our interviews. In Rhos, a significant Welsh-speaking population has persisted through a combination of isolation and activism (Laidlaw, 1995). Densely structured social networks, distinctive social customs and a strong conception of collective identity has been shown to make language transmission effective, and in turn support voluntary institutions and collective activity (Fishman, 1991). However, with social change these bonds have loosened resulting in a decline of both language and social interaction. Some Welsh-medium voluntary groups are still present in Rhos, such as the Cylch Meithrin (Welsh nursery group) and Aelwyd but others - including the local 
Eisteddfod Committee - have withered. Nonetheless, language still confers a particular status in Rhos as described by one of our respondents:

In the community, there are two groups of Welsh people, there are groups of Welsh people that speak Welsh and there are groups of Welsh people that come from Wales that don't necessarily speak Welsh. I always feel that the Welsh speakers feel that they're a little bit closer to God because they speak Welsh, which is a load of bollocks, but I feel that of communities all over Wales and all over the world, if they speak Welsh, they feel a little bit more special' (Cai, Rhos).

\section{Social and economic variables}

Education was the most distinctive factor that we observed accounting for patterns of leadership of voluntary groups, reflecting evidence from previous research (see Smith, 1994). In both villages, we found that trajectories often hinged on early opportunities. Many interviewees linked selection at age eleven for Grammar School to wider opportunities for working class children and subsequent involvement in voluntary leadership:

'I think it's really interesting the connection between the sort of, - really sort of mining area, as you say that kind of manual labour area and then lots of people going to the grammar school from there, and moving on and a lot of you ending up in charge' (Tony, Rhos)

'...no question about it, the grammar school system, it gave some children opportunities that just would not have happened, from very ordinary backgrounds' (Karen, Overton)

In both Overton and Rhos, leaders of voluntary groups were drawn more commonly than not from similar occupational groups. In Overton, many were public servants, or retired business people. In Rhos, there is an oral law that contends that the brightest and best become teachers, and those 
teachers becoming local leaders. As Ifor from Rhos told us:'...there isn't a school in Denbighshire that doesn't have a teacher from Rhos'.

Nevertheless, examination of the 2011 Census reflects differences in socio-economic statuses between the two villages in our study (see Table 1). While Rhos is not wholly working-class, nor is Overton predominantly middle-class, we observe that formal volunteering in both locations is done by those who have ample resources, and that voluntary groups are looking for members of this dominant status group to join them as volunteers. It is predictable therefore that members of lower socioeconomic groups will be marginalized, and as suggested by Hustinx, Cnaan and Handy (2010), will therefore be deprived of opportunities for enhancing the human and social capital that might gain them invitations to participate.

\section{Volunteering 'habitus'}

While many accounts of volunteering focus on social class, Dean (2016) posits that cultural capital and Bourdieu's (1973) concept of habitus should be regarded as a more useful tool in trying to understand the determinants of volunteering. We find strong evidence in our participant narratives of volunteering habits forming during early life through education, social networking and gaining an understanding of social institutions:

'[My family] were very big in volunteering. Father was Chairman of the Ratepayers Association, Tenants and Ratepayers Association, and Chairman of the Village Hall Committee. Mother was a School Governor and also Chairman of the Ladies Conservative Club, the Tea Club. So we always had a background in volunteering.' (James, Overton)

'My life had always been dictated by volunteering I suppose because we were...had a lot to do with [the Church] where my father was a warden, so then you naturally become a choir boy and then you become a server at communion, 
then you read lessons, then you become a Sunday school teacher, and so that's all about volunteering... a commitment to your particular village. It was always the ethic of the family that's what we did' (Tony, Rhos)

While economic categorisation must be considered, in both villages we find volunteer leaders deploying social and cultural capitals relevant to the place. In Rhos, the density of social networks and associated institutions fosters a strong ethos of participation, but seemingly only amongst a relatively small and dwindling cultural elite. We found only one group in Rhos led by an 'outsider' suggesting that within the particular space, capitals accumulated elsewhere have limited value. In contrast, we observe how in Overton the social structures that individuals are brought up with have a value that transcends the space.

\section{Discussion}

In this paper we have revisited the relationship between volunteering and place, moving away from contemporary accounts that see volunteering as choice and an increasingly individualised activity. We have sought to do this by examining practice through the lens of previous studies that identify common determinants, but exploring how volunteering is situated, and the role that place has in structuring the choices that people make.

The literature on individual's attachments to place (O'Toole and Grey, 2016; Pahl, 1968; Savage, Bagnall and Longhurst, 2005) is broadly captured in the term 'belonging', and often concludes, as we do, that people's biographies define their relationship to place. However, Hustinx, Cnaan and Handy's (2010) assertion that volunteering is an expression of belonging that contributes to social integration and inclusion, is just one side of a dichotomous picture that also sees volunteering as a vehicle for division and exclusion.

In Overton we see evidence of factors that positively determine volunteering and participation conspiring to create a vibrant and cohesive local volunteering society. The importance of contextual 
variables such as the size of the village and the mix of housing are evident, and with a high proportion of middle-class migration to the village, we observe participation that reflects Savage's concept of 'elective belonging' (Savage, Bagnall and Longhurst, 2005). However, in a place where volunteering is associated with a sense of belonging without historical roots, we did not find, as Savage, Bagnall and Longhurst (2005) did in some of their study areas, that those born and bred there feel ill at ease. Instead, they accept, and rely upon imported capitals to maintain some traditional activities and develop other new groups and organisations in which they can participate. In contrast, much of the voluntary activity in Rhos, based on intense association, shared culture, language and histories, constitutes an exclusive society within existing boundaries of an already dense working-class community. As one local author observed, 'If there was ever a mafia in Wales they would surely consist of Male Voice Choristers' (Portmadoc-Jones, 1981 in Laidlaw, 1995). Many of our respondents in Rhos spoke about participation in voluntary organisations as a moral duty that carried prestige and status. As Emmett (in Cohen, 1982, p.88) notes, in the past, within heterogeneous working class communities such as Rhos where opportunities for social mobility were restricted, volunteering provided opportunities for individuals to gain social status and accumulate social capital. Rhos is therefore interesting on a number of levels, including as a case study to reflecton whether post-modern culture and globalisation has, as predicted by Harvey \& Hayter (1993), eviscerated post-industrial, working class communities. Our evidence from Rhos suggests that it has not, and despite previous studies charting its demise, it has been transformed just enough to maintain core organisations and structures, but it remains precarious with tradition stifling innovation in local associational life.

The comparison of the volunteering practices in two different locations therefore illustrates the way in which 'belonging', while ultimately an individual sense, can also be a common plurality within places. Identity, belonging, association and volunteering are all part of a feedback circuit that can either reinforce a sense of belonging or make individuals feel excluded (Hothi and Cordes, 2010). In Overton, we find considerable evidence of people volunteering in local groups because they want to 
belong. Their paths to participation are well-worn by previous newcomers to the village and the ease with which many are accepted, encourages new forms of association, participation and in turn, more volunteering. In contrast, in Rhos, people volunteer because they have a strong sense of belonging. Or at least some people do, for in Rhos we find a complex society with divisions related to both assigned and ascribed senses of belonging which requires some to volunteer and prevents others from doing so.

Finally, our discussions with local authorities and third sector organisations around our findings suggest that understanding the relationship between place, belonging and voluntary activity in small groups has practical application. Having insight into people's feelings of belonging within the places they reside clarifies the character of a local area. If this is more clearly understood, public bodies and their partners can tailor engagement and service delivery to have the greatest impact through first, an understanding of local voluntary capacity; and second, knowing when to work with the grain of existing small groups, or against the grain if those groups will, or cannot engage with target populations, such as those often labelled as 'hard to reach'.

\section{Conclusion}

We conclude that within our study sites there is plenty of evidence to show the extent to which volunteering remains embedded in place through local association. We see through our collected narratives that biographies can define the relationship that an individual has with a place and how this affects patterns of volunteering through formations and constructions of identity and belonging. We further conclude however, that contrasting patterns of volunteering alongside disparities in resources can produce division, exclusion and inequalities that need to be understood by external agencies when they develop programmes of support to local voluntary organisations or plan public service delivery that involves local volunteers. 


\section{References}

Arensberg, C. and Kimball, S., 1940. Family and community in Ireland. Cambridge, MA: Harvard University Press

Beck, U., 2002. The Cosmopolitan society and its enemies. Theory, Culture \& Society, 19, 1-2, 17-44

Benson, M. and Jackson, E., 2013. Place-making and place maintenance: Performativity, place and belonging among the middle classes. Sociology, 47, 4, 793-809

Bourdieu, P., 1977. Outline of a theory of practice. Cambridge Studies in Social and Cultural Anthropology. Cambridge University Press

Bourdieu, P., 1986. The forms of capital. In: J.C. Richardson, ed., Handbook of Theory and Research for the Sociology of Education. New York: Greenwood, 241-258

Cabinet Office, 2015. Community Life Survey 2014-2015. London

Cnaan, R.A., Handy, F. and Wadsworth, M., 1996. Defining who is a volunteer: Conceptual and empirical considerations. Nonprofit and Voluntary Sector Quarterly, 25, 3, 364-383

Cohen, A., 1982. Belonging: identity and social organisation in British rural cultures. Manchester: Manchester University Press

Connerton, P., 1989. How societies remember. Cambridge: Cambridge University Press

Cornwall, A., 2002. Making spaces, changing spaces: situating participation in development. IDS Paper 170, 43

Curtis, A., 2015. Volunteering in the Downturn. Institute for Volunteering Research, London.

Day, G. (ed), 1998. Nation, nationalism and ethnicity. In: Making Sense of Wales. Cardiff: University of Wales Press, 230-257

Dean, J., 2014. How structural factors promote instrumental motivations within youth volunteering: a qualitative analysis of volunteer brokerage. Voluntary Sector Review, 5, 2, 231-247

Dean, J., 2015. Volunteering, the market, and neoliberalism. People, Place \& Policy, 9, 2, 139-148

Dean, J., 2016. Class diversity and youth volunteering in the UK: Applying Bourdieu's habitus and cultural capital. Nonprofit and Voluntary Sector Quarterly, 45, 1, 1-34

Eckstein, S., 2001. Community as gift-giving: collectivistic roots of volunteerism. American Sociological Review, 66, 6, 829-854

Fine, G.A. and Harrington, B., 2004. Tiny publics: Small groups and civil society. Sociological Theory, $22,3,341-356$

Fishman, J., 1991. Reversing language shift: Theoretical and empirical foundations of assistance to threatened languages. Multilingual Matters, 76

Frankenberg, R., 1957. Village on the Border: A Social Study of Religion, Politics and Football in a North Wales Community. Manchester: Manchester University Press

Grönlund, H., 2013. Cultural values and volunteering: A cross-cultural perspective. In: D. Vakoch, ed., Altruism in Cross-Cultural Perspective. New York: Springer, 71-84

Handy, F., Cnaan, R., Brudney, J., Ascoli, U., Meijs, L. and Ranade, S., 2000. Public perception of 'who is a volunteer': An examination of the net-cost approach from a cross-cultural perspective. 
International Journal of Voluntary and Nonprofit Organizations, 11, 1, 45-65

Handy, F., Hustinx, L. and Cnaan, R., 2009. A cross-cultural examination of student volunteering: Is it all about résumé building? Nonprofit and Voluntary, 39, 3, 498-523

Harper, S., 1989. The British rural community: an overview of perspectives. Journal of Rural Studies, $5,2,161-184$

Hayter, T. and Harvey, D. eds., 1993. The factory and the city : the story of the Cowley automobile workers in Oxford. London: Mansell

Henderson, A., Brown, S.D., Pancer, S.M. and Ellis-Hale, K., 2007. Mandated community service in high school and subsequent civic engagement: The case of the 'Double Cohort' in Ontario, Canada. Journal of Youth and Adolescence, 36, 7, 849-860

Hothi, M. and Cordes, C., 2010. Understanding neighbourliness and belonging. London: The Young Foundation

Hustinx, L. and Meijs, L., 2011. Re-embedding volunteering: In search of a new collective ground. Voluntary Sector Review, 2, 1, 5-21

Hustinx, L., 2010. Institutionally individualized volunteering: Towards a late modern re-Construction. Journal of Civil Society, 6, 2, 165-179

Hustinx, L., Cnaan, R.A. and Handy, F., 2010. Navigating theories of volunteering: A hybrid map for a complex phenomenon. Journal for the Theory of Social Behaviour, 40, 4, 410-434

Janoski, T., Musick, M. and Wilson, J., 1998. Being volunteered? The impact of social participation and pro-social attitudes on volunteering. Sociological Forum, 13, 3, 495-519

Laidlaw, R., 1995. Community, Work and Religion: Mentalities in the villages of the North Wales coalfield c.1930-c.1960. Warwick University

Lewicka, M., 2008. Place attachment, place identity, and place memory: Restoring the forgotten city past. Journal of Environmental Psychology, 28, 3, 209-231

Mann, R., 2007. Negotiating the politics of language: Language learning and civic identity in Wales.

Ethnicities, 7, 2, 208-224

Mccabe, A. and Phillimore, J., 2012. All Change? Surviving 'below the radar': community groups and activities in a Big Society. Working Paper. Third Sector Research Centre, Birmingham

Musick, M.A. and Wilson, J., 2008. Volunteers: A social profile. Bloomington, Indiana: Indiana University Press

O'Toole, M. and Grey, C., 2016. Beyond choice: 'Thick' volunteering and the case of the Royal National Lifeboat Institution. Human Relations, 69, 1, 85-109

ONS, 2011. Neighbourhood Statistics. www.neighbourhood.statistics.gov.uk

Pahl, R., 1968. Readings in urban sociology. Oxford: Pergamon Press

Pahl, R., 2005. Are all communities communities in the mind? Sociological Review, 53, 4, 621-640

Pahl, R., 2008. Hertfordshire commuter villages: From geography to sociology. International Journal of Social Research Methodology, 11, 2, 103-107

Parsons, E. and Broadbridge, A., 2006. Job motivation and satisfaction: Unpacking the key factors for charity shop managers. Journal of Retailing and Consumer Services, 13, 2, 121-131 
Patton, M.Q., 2005. Qualitative Research. Chichester: John Wiley \& Sons

Phillipson, C., 2012. Community studies and re-studies in the 21st century: methodological challenges and strategies for the future. The Sociological Review, 60, 3, 537-549

Putnam, R., 2001. Bowling alone: The collapse and revival of American community. New York: Simon and Schuster

Rochester, C., 2013. Rediscovering voluntary action: The beat of a different drum. Basingstoke:

Palgrave Macmillan

Rosenthal, G. (2004). Biographical research. In: Seale, C. ed., Qualitative research practice. London : Sage, 48-64

Savage, M., Bagnall, G. and Longhurst, B., 2005. Globalization and belonging. London: SAGE

Savage, M., Bagnall, G. and Longhurst, B.J., 2004. Globalization and belonging. London: SAGE

Simpson, K., 2004. 'Doing development': The gap year, volunteer-tourists and a popular practice of development. Journal of International Development, 16, 5, 681-692

Smith, D., 1983. Synanthrometrics: On the progress in the development of a general theory of voluntary action and citizen participation. In: International perspectives on voluntary action research. Washington, DC: add publisher, 80-94

Smith, D.H., 1994. Determinants of voluntary association participation and volunteering: A literature review. Nonprofit and Voluntary Sector Quarterly, 23, 3, 243-263

Smith, D.H., 1997. The rest of the nonprofit sector: Grassroots associations as the 'dark matter' ignored in prevailing 'flat earth' maps of the sector. Nonprofit and Voluntary Sector Quarterly, 26, 2, 114-131

Taylor, R., Phillimore, J., McCabe, A. and Soteri-Proctor, A., 2010. Understanding the distinctiveness of small scale, third sector activity: The role of local knowledge and networks in shaping below the radar actions. Working Paper. Birmingham

Taylor, R.F., 2004. Extending conceptual boundaries: Work, voluntary work and employment. Work, employment and society, 18,1, 29-49

The Chapels Heritage Society, 1988. Rhosllanerchrugog. Capel Newsletter.

www.capeli.org.uk/uploads/local_05_rhosllanerchrugog.pdf

Tönnies, F., 1955. Community and society. New York: Harper \& Row

Tyler, K., 2003. The racialised and classed constitution of English village life. Journal of Anthropology Museum of Ethnography, 68, 3, 391-412

Urry, J., 2003. Global Complexity. Cambridge: Polity

Warburton, J. and Smith, J., 2003. Out of the generosity of your heart: Are we creating active citizens through compulsory volunteer programmes for young people in Australia? Social Policy and

Administration, 37, 7, 772-786

Wilson, J. and Musick, M., 1997. Work and volunteering: The long arm of the job. Social Forces, 76, 1, 251-272

Wilson, J., 2000. Volunteering. Annual Review of Sociology, 26, 1, 215-240

Wollebaek, D. and Selle, P., 2002. Does participation in voluntary associations contribute to social capital? The impact of intensity, scope, and type. Nonprofit and Voluntary Sector Quarterly, 31, 1, 
Zaff, J.F., Malanchuk, O. and Eccles, J.S., 2008. Predicting positive citizenship from adolescence to young adulthood: The effects of a civic context. Applied Developmental Science, 12, 1, 38-53 
Figures and Tables

Table 1: Determinants of Volunteering: Analytical Framework

\begin{tabular}{|l|l|l|}
\hline Coding variables & Definitions & Inductive coding categories \\
\hline Contextual & $\begin{array}{l}\text { Characteristics of the } \\
\text { environment - size of } \\
\text { settlement, regional influences, } \\
\text { rurality, industry }\end{array}$ & $\begin{array}{l}\text { History } \\
\text { Environment } \\
\text { Migration }\end{array}$ \\
\hline Situational & $\begin{array}{l}\text { Symbolic interactions between } \\
\text { individuals. Friendships, family } \\
\text { ties, status, service use }\end{array}$ & $\begin{array}{l}\text { Language } \\
\text { Membership of other groups } \\
\text { Being asked to volunteer } \\
\text { Existing service user }\end{array}$ \\
\hline $\begin{array}{l}\text { Socio-economic and } \\
\text { demographic }\end{array}$ & $\begin{array}{l}\text { Gender, social class, education } \\
\text { level, ethnicity, age }\end{array}$ & $\begin{array}{l}\text { Education } \\
\text { Gender } \\
\text { Occupational status }\end{array}$ \\
\hline Habitus & $\begin{array}{l}\text { Predispositions acquired } \\
\text { through practice }\end{array}$ & $\begin{array}{l}\text { Early socialisation } \\
\text { Family history of participation } \\
\text { Cultural status }\end{array}$ \\
\hline
\end{tabular}

Table 2: Key statistics for the parishes of Rhosllannerchrugog and Overton

\begin{tabular}{|c|c|c|c|c|c|c|c|c|c|c|}
\hline & $\begin{array}{l}\text { All Usual } \\
\text { Residents }\end{array}$ & $\begin{array}{l}\text { Residents } \\
\text { born in } \\
\text { Wales }\end{array}$ & $\begin{array}{l}\text { Residents } \\
\text { born } \\
\text { outside } \\
\text { the UK }\end{array}$ & $\begin{array}{l}\text { Residents } \\
\text { of } \\
\text { working } \\
\text { age }, 19 \\
\text { to } 64 \text { ) }\end{array}$ & $\begin{array}{l}\text { Can } \\
\text { speak } \\
\text { Welsh* }\end{array}$ & $\begin{array}{l}\text { Residents } \\
\text { describing } \\
\text { themselves } \\
\text { as } \\
\text { Christian }\end{array}$ & $\begin{array}{l}\text { High level } \\
\text { occupations* }\end{array}$ & $\begin{array}{l}\text { Intermediate } \\
\text { level } \\
\text { occupations* }\end{array}$ & $\begin{array}{l}\text { Lower level } \\
\text { occupations* }\end{array}$ & $\begin{array}{l}\text { Not } \\
\text { working* }\end{array}$ \\
\hline Rhos & 9,694 & $82 \%$ & $4 \%$ & $58 \%$ & $24 \%$ & $60 \%$ & $9 \%$ & $37 \%$ & $47 \%$ & $11 \%$ \\
\hline Overton & 3,315 & $51 \%$ & $5 \%$ & $57 \%$ & $9 \%$ & $44 \%$ & $22 \%$ & $52 \%$ & $28 \%$ & $6 \%$ \\
\hline
\end{tabular}

Source: Office for National Statistics, Census 2011

* Derived variable 
Figure 1: On a scale of 1 to 6, where 6 is 'feel very strongly', and 1 is 'not at all', would you consider yourself to be... , $n=180$ )

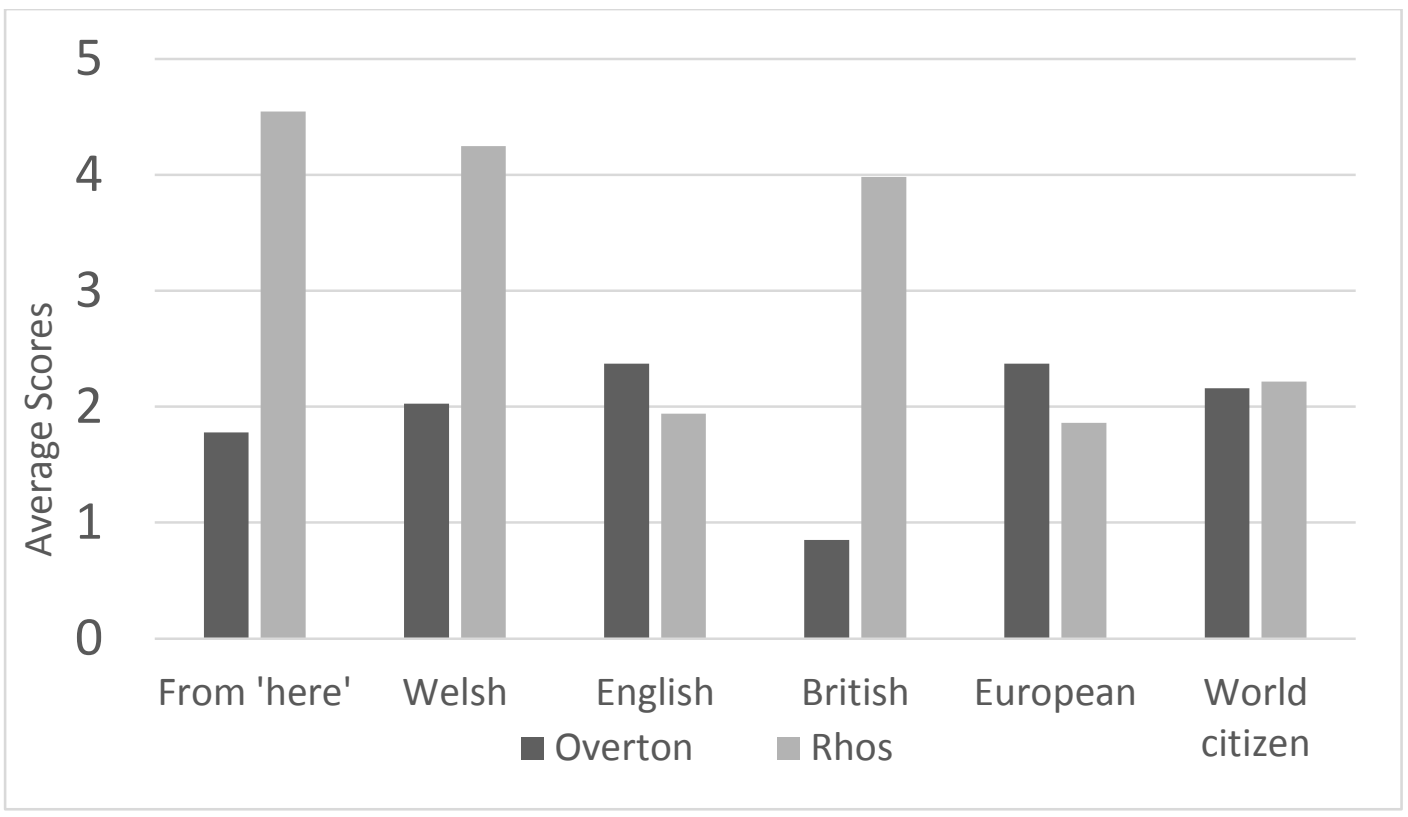

